\title{
Contrasting lithospheric mantle across the suture between the Eastern and Western Dharwar Cratons, central India
}

\author{
W.L. Griffin ${ }^{1}$, A. F. Kobussen ${ }^{1}$, E.V.S.S.K. Babu ${ }^{2}$, S.Y. O'Reilly ${ }^{1}$, R. Norris ${ }^{3}$, P. Sengupta ${ }^{3}$ \\ ${ }^{I}$ GEMOC, Dept. Earth \& Planetary Sciences, Macquarie Univ., NSW 2109, Australia \\ ${ }^{2}$ National Geophysical Research Inst., Hyderabad 500 007, India \\ ${ }^{3}$ Rio Tinto Exploration India, Whitefield, Bangalore 560 066, India
}

\section{Introduction and Methods}

The Dharwar craton consists of two major blocks: in the Western Dharwar (WDC) 3.3-2.6 Ga supracrustal rocks overlie a 3.4-2.9 Ga basement; in the Eastern Dharwar (EDC) 2.6-2.5 Ga calc-alkaline granitoids enclose narrow belts of $2.7 \mathrm{Ga}$ supracrustals. The EDC appears to have been thrust westward over the WDC prior to $2.5 \mathrm{Ga}$; the suture may be represented by a major mylonite zone (the Chitradurga schist belt) or by the Closepet Granite, a narrow batholith that runs N-S for ca $300 \mathrm{~km}, 40-50 \mathrm{~km} \mathrm{E}$ of the schist belt. Garnet concentrates and mantle-derived xenoliths from 1.0-1.1 Ga kimberlite clusters in Andra Pradesh provide images of the subcontinental lithospheric mantle (SCLM) along a traverse extending SW-NE across the E margin of the Closepet Granite (Fig. 1).

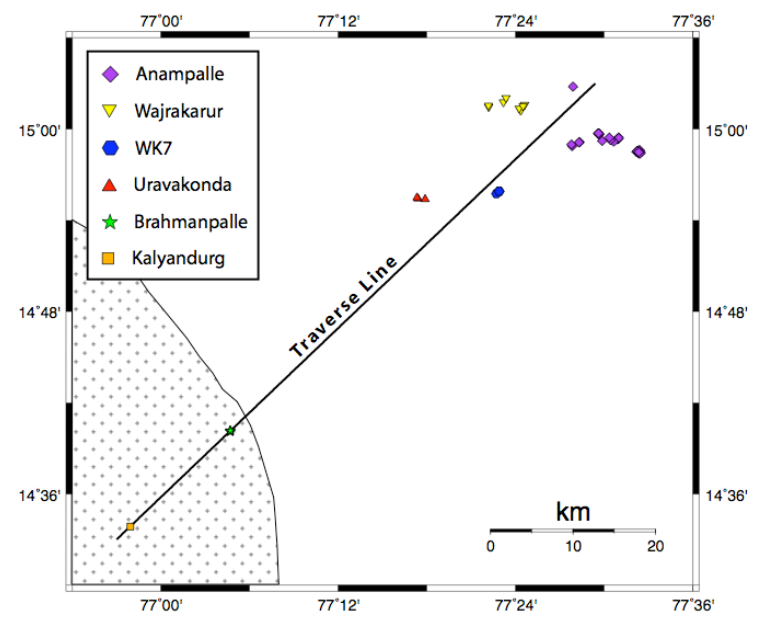

Figure 1. Locations of kimberlite clusters studied with traverse line. Igneous pattern indicates the Closepet Granite.

Geotherms for the SCLM beneath each cluster have been derived from major- and trace-element compositions of peridotitic garnets as described by
Ryan et al. (1996). The calculation of $X_{\mathrm{Mg}}$ in olivine coexisting with individual garnet grains is described by Gaul et al. (2000) and the derivation of whole-rock (WR) $\mathrm{Al}_{2} \mathrm{O}_{3}$ contents from garnets by Griffin et al. (1998). Eclogite data used here are from this work $(\mathrm{n}=18)$, Ganguly and Bhattacharya $(1987 ; n=4)$ and Patel et al. $(2006 ; n=10)$. Depth estimates for eclogites are defined by the intersection of P-T trajectories (Krogh, 1988) with the garnet geotherm, assuming that eclogites and peridotites have equilibrated to a common geotherm (Griffin and O'Reilly, 2007).

\section{Results}

The Kalyandurg and Brahmanpalle clusters at the SW end of the traverse sampled typical Archean SCLM, with a low geotherm $\left(35 \mathrm{~mW} / \mathrm{m}^{2}\right)$ and harzburgitic to lherzolitic rocks with median $\mathrm{X}_{\mathrm{Mg}}$ olivine $>$ 0.93 and median whole-rock $\mathrm{Al}_{2} \mathrm{O}_{3}<1 \%$. The base of the depleted lithosphere at $185-195 \mathrm{~km}$ depth is marked by a $10-15 \mathrm{~km}$ layer of strongly metasomatised peridotites $\left(\mathrm{X}_{\mathrm{Mg}}\right.$ olivine $\left.\approx 88\right)$. The Anampalle and Wajrakarur clusters $60 \mathrm{~km}$ to the NW show a distinctly different SCLM; it has a higher geotherm (37.5-40 $\mathrm{mW} / \mathrm{m}^{2}$ ), contains few subcalcic harzburgites, and has median $\mathrm{X}_{\mathrm{Mg}}$ olivine $\leq 0.925$ and median whole-rock $\mathrm{Al}_{2} \mathrm{O}_{3}$ $\approx 2 \%$. Kimberlites of the Uravakonda and WK-7 clusters, midway along the traverse, sampled a quite fertile (median $\mathrm{X}_{\mathrm{Mg}}$ olivine $\approx 0.915$, median $\mathrm{WR} \mathrm{Al}_{2} \mathrm{O}_{3}$ $\approx 3 \%$ ) SCLM with an elevated geotherm $\left(>40 \mathrm{~mW} / \mathrm{m}^{2}\right)$.

The data from $>1080$ peridotitic garnet xenocrysts have been used to map the vertical and lateral variations in key chemical parameters (Figs 24). The techniques used for gridding and contouring the data are described by Kobussen et al. (2008). 


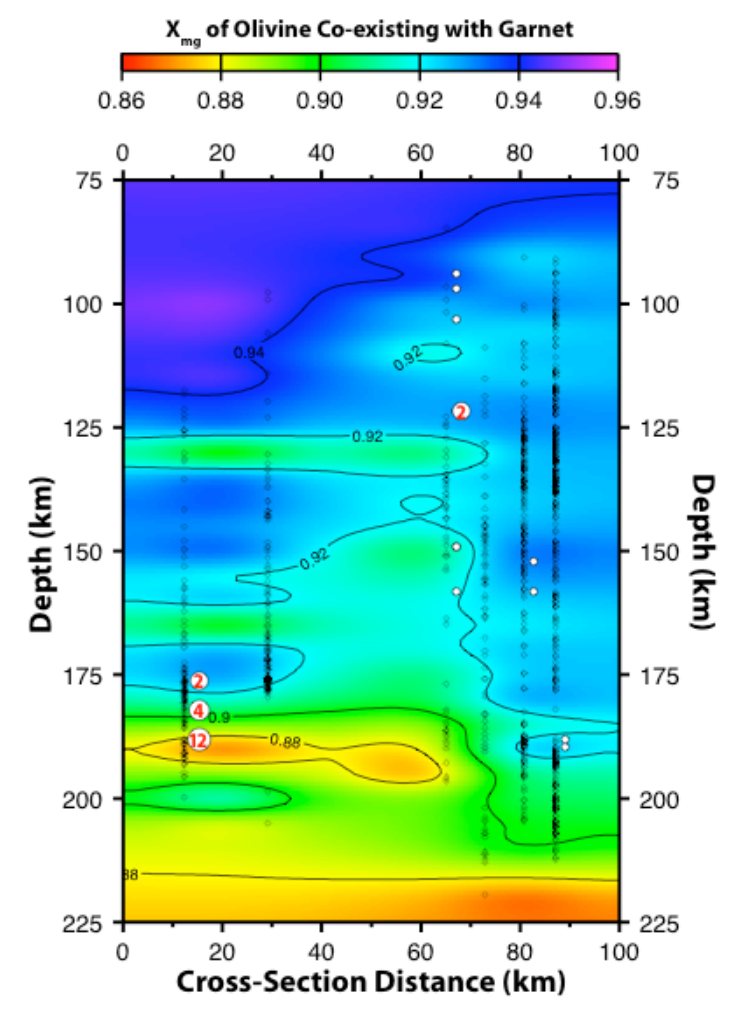

Figure 2. Distribution of median calculated $X_{M g}$ of olivine coexisting with Cr-pyrope garnets. Diamonds, individual data points. Circles, eclogites (numbers show $>1$ sample with similar depth estimate. The gridding and filtering algorithm elements used are 20 $\mathrm{km}$ wide by $5 \mathrm{~km}$ deep.

The $\mathrm{X}_{\mathrm{Mg}}$ of olivine (Fig. 2) shows marked vertical and lateral variations. In the Kalyandurg $(16 \mathrm{~km}$ on the traverse) and Brahmanpalle (29 km) sections, relatively depleted material $\left(\mathrm{X}_{\mathrm{Mg}}>0.93\right)$ is interspersed with bands of lower $\mathrm{X}_{\mathrm{Mg}}$, and median $\mathrm{X}_{\mathrm{Mg}}$ drops to $\leq 0.88$ between 180-195 km depth. This Fe-enriched layer corresponds to a strong concentration of eclogites. The section beneath the Uravakonda and WK-7 clusters $(65-75 \mathrm{~km})$ is strikingly less magnesian, with few values of $\mathrm{X}_{\mathrm{Mg}} \geq 0.92$. The available data suggest that eclogites are distributed throughout the section from ca $85-160 \mathrm{~km}$. The SCLM beneath the most northerly clusters $(80-90 \mathrm{~km})$ is more uniform in composition, but is significantly less magnesian than the SW end of the traverse, especially at depths $<125 \mathrm{~km}$. The few eclogite data from these fields spread between 150-190 km depth.

Figure 3 shows sharp rises in the Ti contents of garnets at depths varying from ca $180 \mathrm{~km}$ in the middle of the traverse to ca $190 \mathrm{~km}$ at the NE end. This pattern is typical of many SCLM sections worldwide, and the chemistry of these higher-Ti garnets can be correlated with the garnets of high-T sheared, meltmetasomatised garnets. We take this signal as defining the base of the depleted SCLM, and a level of

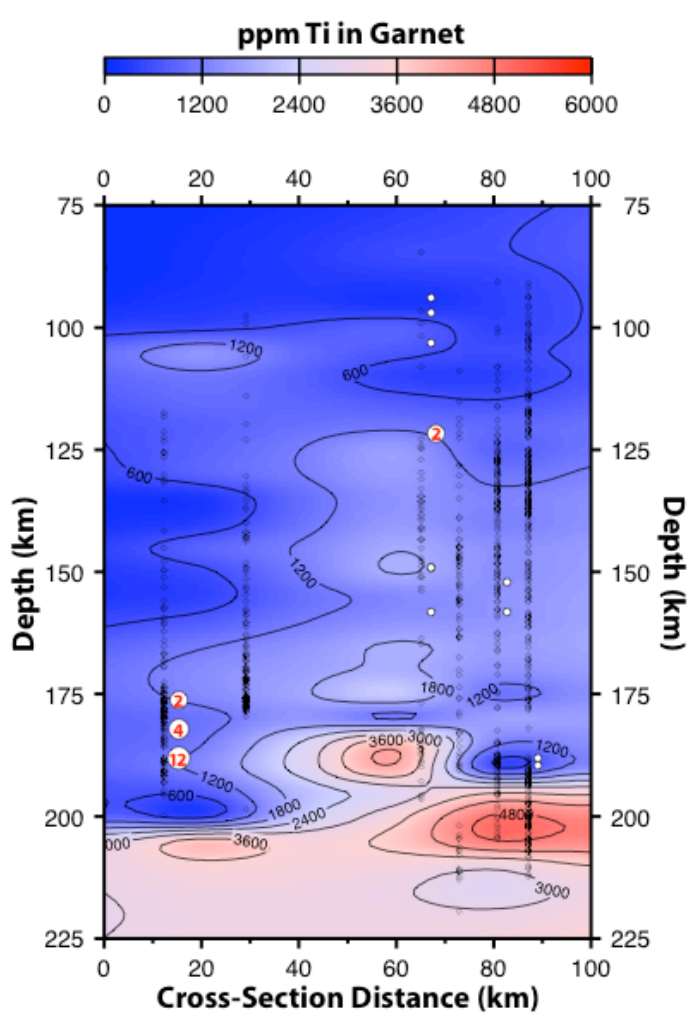

Figure 3. Distribution of median Ti contents (ppm) of Cr-pyrope garnets.

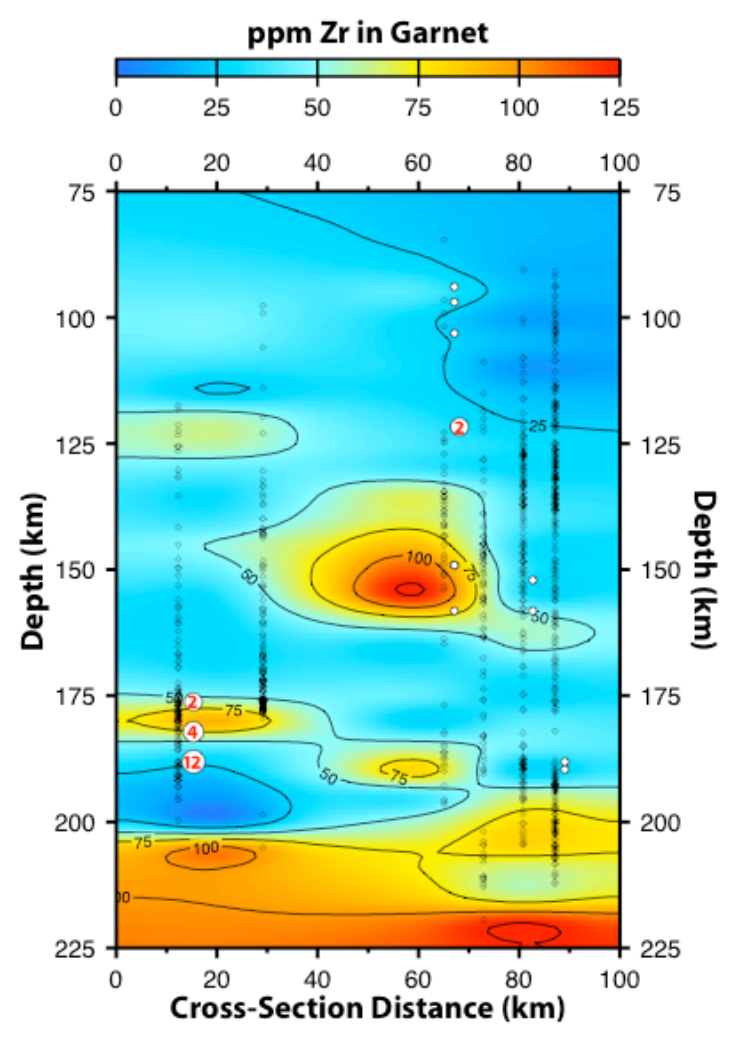

Figure 4. Distribution of median $\mathrm{Zr}$ contents (ppm) of Cr-pyrope garnets. 
magma ponding and infiltration. This increase in $\mathrm{Ti}$ is not well-defined beneath the SW end of the traverse; the intense Fe-metasomatism at $180-195 \mathrm{~km}$ depth is accompanied by only a relatively modest rise in the median $\mathrm{Ti}$ in garnet. The section beneath the Uravakonda and WK-7 clusters is generally higher in Ti than the SCLM at the NE or SW ends of the traverse. The distribution of median $\mathrm{Zr}$ in garnet (Fig. 4) tends to mirror that of $\mathrm{Ti}$, with two marked differences: a large increase at ca $150 \mathrm{~km}$ depth in the middle of the traverse, and another at $175-180 \mathrm{~km}$ depth beneath the SW end.

Beneath the Kalyandurg cluster $(16 \mathrm{~km})$, there is a strong correlation between the distribution of eclogites and enrichment of the peridotites in $\mathrm{Fe}$ and $\mathrm{Zr}$. We suggest a genetic connection, with the peridotites being metasomatised by mafic melts and associated fluids. The strong concentration of eclogites in a $10-20 \mathrm{~km}$ layer beneath the Kalyandurg cluster is similar to that seen in many SCLM sections (Griffin and O'Reilly, 2007) and contrasts with the broader depth distribution of eclogites beneath the fields to the NE. There is also a marked difference in eclogite types: many of the Kalyandurg eclogites are kyanitebearing ( \pm coesite), and the bimineralic eclogites tend to have the high-Ca garnet that is characteristic of the kyanite eclogites, suggesting they belong to the same suite. The eclogites from the pipes to the NE are more typical bimineralic eclogites with generally higher $\mathrm{Mg \#}$ and lower-Ca garnets.

\section{Conclusions}

(1) The striking differences in the SCLM (100-200 km depth) along the traverse suggest that the NE and SW ends of the traverse represent distinct lithospheric blocks, corresponding to the EDC and WDC.

(2) At 100-200 km depth, the EDC - WDC suture lies near the E margin of the Closepet Granite, suggesting that the batholith is the crustal expression of a lithosphere-scale boundary.

(3) The SCLM near the suture is strongly refertilised, perhaps during craton assembly.

(4) The differences in the SCLM beneath the WDC and EDC suggest that each cratonic block carried its own "root" at the time of their collision; the root beneath the margin of the EDC may already have been less depleted, or it may have been refertilised by fluids moving along the suture.

(5) The scarcity of kyanite eclogites beneath the EDC margin suggests that the WDC eclogites were emplaced before craton assembly.

\section{References}

Ganguly, J., Bhattacharya, P.K., 1987. Xenoliths in Proterozoic kimberlites from southern India: petrology and geophysical implictions. In Nixon, P.H. (ed.) Mantle Xenoliths, Wiley, New York, pp. 249-266.

Gaul, O.F., Griffin, W.L., O'Reilly, S.Y., Pearson, N.J., 2000. Mapping olivine composition in the lithospheric mantle. Earth and Planetary Science Letters 182, 223-235.

Griffin, W.L., O'Reilly, S.Y., Ryan, C.G., Gaul, O., Ionov, D. 1998. Secular variation in the composition of subcontinental lithospheric mantle. In Braun, J., Dooley, J.C., Goleby, B.R., van der Hilst, R.D., Klootwijk, C.D. (Eds), Structure and Evolution of the Australian Continent, Geodynamics Volume 26, American Geophysical Union, Washington D.C. pp. 1-26.

Griffin, W.L., O’Reilly, S.Y., 2007. Cratonic lithospheric mantle: Is anything subducted? Episodes 30, 43-53.

Kobussen, A.F., Griffin, W.L., O'Reilly, S.Y., Shee, S.R., 2008. The ghosts of lithospheres past: Imaging an evolving lithospheric mantle in southern Africa. Geology 36, 515-518.

Krogh, E. R., 1988. The garnet-clinopyroxene Fe-Mg geothermometer - a reinterpretation of existing experimental data. Contributions to Mineralogy and Petrology 99, 44-48.

Patel, S.C., Ravi, S., Thakur, S.S., Rao, T.K., Subbaroa, K.V. 2006. Mineralogy and Petrology 88, 363-380.

Ryan, C.G., Griffin, W.L., Pearson, N.J., 1996. Garnet Geotherms: a technique for derivation of P-T data from Cr-pyrope garnets. Journal of Geophysical Research 101, 5611-5625. 